Proc. of JSCE,

No. 191, July 1971

\title{
A FUNCTION OF FREE LIME AND CHARACTERISTICS OF CEMENT HYDRATION IN COMPACTED CLAY-CEMENT MIXTURES
}

\author{
By Mitsunori KAWAMURA*, Shigemasa HASABA** \\ and Seiji SUGIURA***
}

\section{INTRODUCTION}

As far as the compacted soil-cement mixtures as a material for road paving are concerned, only a few reports of the clay minerals-cement physicochemical interaction are found $\left.\left.\left.\left.{ }^{1,}, 2\right), 3\right), 4,, 55,6\right), 7\right)$ However, a great number of problems remain uncertain. Among these, no report concerning the characteristics of cement hydration in the clay-cement mixtures compacted under a very limited moisture content can be found, although the subject is much important for the better understanding of the physicochemical properties of soil-cement mixtures. The far greater volume fraction of pore space and the presence of reactive clay minerals in soil-cementmixture suggest that the hydration of cement particles in the mixtures proceeds under a very different environment from that in the usual cement paste.

Cement hydration process in compacted clay-cement mixtures still remains uncertain. Based on Shestoperv's theory on cement hydration, Bezruk mentioned that the hydrolysis and hydration of cement surrounded by reactive substances are retarded in one case, while acceralated in another ${ }^{8}$. For example, experiments by isothermal calorimetry indicate that the hydration of the $\mathrm{C}_{3} \mathrm{~S}$ is influenced very little by gibbsite; it is influenced by bayrite to a somewhat large extent ${ }^{9)}$. Therefore, it may be presumed that the degree of the crystallinity of clay minerals used has a delicate effect on cement hydration in clay-cement mixtures. Recently, an attempt is made on the utilization of some clay minerals as an admixture in concrete. In this case, the interaction between clay minerals and hydrating

* Assistant Professor, Department of Civil Engineering, Kanazawa University, Kanazawa

** Professor, Department of Civil Engineering, Kanazawa University, Kanazawa

*** Professor, Department of Earth Sciences, Kanazawa University, Kanazawa cement should also be important. Lipowski proposed that the powdered and dried clays could be mixed with cement to produce a new cementing material desirable for the production of concretes ${ }^{10}$. $\mathrm{He}$ obtained several experimental results concerning the physicochemical phenomena in the hardening process of the material. The results obtained are as follows:

The specific surface of powdered clay added highly affects the hydration of the cement. The adsorption of $\mathrm{Ca}^{2+}$ ion to clay minerals occurs on hydration of the mixtures. It accelarates the hydrolysis of alite, so that its setting and hardening behaviors become considerably different from those of the usual additive-free portland cement.

One of the important problems associated with cement stabilization of soils is the limited amount of time after mixing available for manipulation, testing and possible remanipulation. As a possible solution to this problem, the use of set-retarding admixtures is being investigated by the workers in Virginia Highway Research Council ${ }^{11,12}$. In this respect, understanding the characteristics of hydration rate of alite and belite in compacted claycement mixtures would be much interesting in practical application as well. The clay-cement system is so complex that the nature of the problem can not throughly be disclosed only by investigating the reduction behavior of the quantity of alite and belite accompanying their hydration. Especially, in the system in which reactive substaces exist, it may be extremely important to elucidate the behavior of free lime resulting from cement hydration. From the above aspect, this paper gives several experimental discussions on the following three problems.

The first is to discuss in detail the reduction rate of the quantities of alite and belite in kaoliniteand bentonite-cement accompanying their hydration by the use of the $\mathrm{X}$ ray diffraction method. Types of cement selected are high-early-strength and moderate-heat cement. The difference between the relative proportions of the constituents (alite and 
belite) included in these two types of cement must affect the strength development of clay mineralscement mixtures and physicochemical interaction between cement and clay minerals.

The second is to compare the experimental results of clay-cement mixtures with those of clay- $\mathrm{Ca}(\mathrm{OH})_{2}$ ones in order to understand the function of free lime in the mixtures. Then, in the preparation of specimens for various tests, the calcium hydroxide of 9, 6 and 3 percent by weight of dry clay is added to clay mineral samples corresponding to the comparable clay-cement mixtures of 30,20 and 10 percent cement content, respectively. The amount of $\mathrm{Ca}(\mathrm{OH})_{2}$ added is determined based on the fact that the complete hydration of portland cement libelates the calcium hydroxide of about 30 percent by weight of cement.

Chlorite-vermiculite mixed-layer mineral and allophane-cement mixtures seem to show a specific reaction process. Finally, the cement hydration in these mixtures and the characteristics of their strength development would be experimetally discussed.

\section{MATERIALS AND OUTLINE OF EX- PERIMENTS}

Table 1 Chemical Compositions of Cements

\begin{tabular}{l|r|r|r}
\hline \multicolumn{1}{c|}{ Cement } & Normal & $\begin{array}{c}\text { High-Early- } \\
\text { Strength }\end{array}$ & $\begin{array}{r}\text { Moderate- } \\
\text { Heat }\end{array}$ \\
\hline $\mathrm{SiO}_{2}(\%)$ & 22.3 & 20.8 & 23.2 \\
$\mathrm{Al}_{2} \mathrm{O}_{3}(\%)$ & 5.4 & 4.6 & 4.9 \\
$\mathrm{Fe}_{2} \mathrm{O}_{3}(\%)$ & 3.2 & 2.8 & 3.9 \\
$\mathrm{CaO}(\%)$ & 64.7 & 66.0 & 64.3 \\
$\mathrm{MgO}_{\mathrm{g}}(\%)$ & 1.2 & 1.4 & 1.3 \\
$\mathrm{SO}_{3}(\%)$ & 1.6 & 2.7 & 1.6 \\
$\mathrm{Jg}$. Loss (\%) & 0.5 & 0.8 & 0.4 \\
Insol. & 0.1 & 0.2 & 0.1 \\
Total & 99.0 & 99.3 & 99.3 \\
\hline $\mathrm{C}_{3} \mathrm{~S}(\%)$ & 49 & 69 & 45 \\
$\mathrm{C}_{2} \mathrm{~S}(\%)$ & 27 & 8 & 33 \\
$\mathrm{C}_{3} \mathrm{~A}(\%)$ & 9 & 8 & 5 \\
$\mathrm{C}_{4} \mathrm{AF}(\%)$ & 10 & 9 & 12 \\
\hline
\end{tabular}

\section{A. Experiments}

(a) X-ray diffraction, (b) Thermal analysis, (c) $\mathrm{pH}$ test, (d) Unconfined compression test

\section{B. Materials and Preparation of Samples}

\section{(1) Cements and Calcium Hydroxide}

Cements used are the normal, high-early-strength and moderate-heat commercial portland cement. The $\mathrm{Ca}(\mathrm{OH})_{2}$ used is freshly-opened the first grade reagent which was supplied by Katayama pharmaceutical Co.. Chemical compositions of cements are given in Table 1

\section{(2) Clay Mineral Samples}

Bentonite is supplied by the Kanto Bentonite Co., Kaolinite ( $\mathrm{Ka}(\mathrm{I}), \mathrm{Ka}(\mathrm{II}), \mathrm{Ka}(\mathrm{III})$ ) from Hiraki, Hyogo Prefecture is made under $105 \mu$ by grinding the respective rocks. Chlorite-vermiculite mixed-layer mineral and allophane (A(I) and $A(I I))$ are from Noto, Ishikawa Prefecture and Hattori, Nagano Prefecture, respectively.

The predominant clay and non-clay minerals contained in samples and their physical properties are presented in Table 2. The chemical composition

Table 3 Chemical Compositions and Cation Exchange Capacity

\begin{tabular}{l|r|r|r|r}
\hline & Bentonite & $\begin{array}{c}\text { Kaolinite } \\
(\mathrm{Ka}(\text { II }))\end{array}$ & $\begin{array}{c}\text { Mixed- } \\
\text { Layer }\end{array}$ & $\begin{array}{c}\text { Allophane } \\
(\mathrm{A}(\text { II }))\end{array}$ \\
\hline $\mathrm{Sio}_{2}(\%)$ & 70.98 & 50.34 & 67.00 & 52.07 \\
$\mathrm{Al}_{2} \mathrm{O}_{3}(\%)$ & 16.41 & 34.82 & 16.96 & 28.45 \\
$\mathrm{Fe}_{2} \mathrm{O}_{3}(\%)$ & 1.92 & 0.64 & 3.18 & 2.23 \\
$\mathrm{CaO}(\%)$ & 0.56 & 0.78 & 0.84 & 2.57 \\
$\mathrm{M}_{9} \mathrm{O}(\%)$ & 2.17 & 0.33 & 1.90 & 0.36 \\
$\mathrm{Na}_{2} \mathrm{O}(\%)$ & 0.15 & 0.43 & 0.32 & 0.26 \\
$\mathrm{~K}_{2} \mathrm{O}(\%)$ & 0.23 & 0.64 & 0.24 & 0.45 \\
\hline Cation & & & & \\
Exchange & 73 & 7.4 & 8.6 & 25 \\
Capacity \\
(meq./100g) & & & & \\
\hline
\end{tabular}

Note : Cation exchange capacity of allophane (A(I)) is 27 meq./ $100 \mathrm{~g}$.

Table 2 Physical Properties

\begin{tabular}{|c|c|c|c|c|c|c|c|}
\hline \multirow{2}{*}{ Properties } & \multirow{2}{*}{ Bentonite } & \multicolumn{3}{|c|}{ Kaolinite } & \multirow{2}{*}{ Mixed-Layer } & \multicolumn{2}{|c|}{ Allophane } \\
\hline & & $\mathrm{Ka}(\mathrm{I})$ & $\mathrm{Ka}($ II $)$ & $\mathrm{Ka}($ III $)$ & & $A(I)$ & $\mathrm{A}(\mathrm{II})$ \\
\hline Size Ranges : $>74 \mu(\%)$ & 00 & 58 & 25 & 17 & 1 & 40 & 44 \\
\hline $74-5 \mu(\%)$ & 17 & 35 & 69 & 73 & 92 & 43 & 30 \\
\hline$<5 \mu(\%)$ & 83 & 7 & 7 & 10 & 7 & 17 & 26 \\
\hline L.L. (\%) & 328 & 25.3 & 33.0 & 34.2 & 77.0 & 137 & 88.0 \\
\hline P.L. $(\%)$ & 41 & 17.3 & 20.5 & 18.6 & 27.1 & 106 & \\
\hline P.I. & 277 & 8.0 & 9.5 & 15.6 & 49.9 & 31 & $\mathbf{N} \cdot \mathrm{P}$ \\
\hline Maximum Dry Density $\left(\mathrm{g} / \mathrm{cm}^{3}\right)$ & 1.015 & 1.860 & 1.770 & 1.720 & 1.535 & 0.920 & 0.950 \\
\hline Optimum Moisture Content (\%) & 50.0 & 13.7 & 15.1 & 18.4 & 23.5 & 66.5 & 58.5 \\
\hline $\begin{array}{l}\text { Predominant Clay and Non-clay } \\
\text { Minerals }\end{array}$ & $\begin{array}{c}\text { montmo- } \\
\text { rillonite, } \\
\text { cristobalite }\end{array}$ & \multicolumn{3}{|c|}{ kaolinite, quartz } & $\begin{array}{l}\text { chlorite-vermiculite } \\
\text { mixed-layer mineral, } \\
\text { quartz }\end{array}$ & \multicolumn{2}{|c|}{$\begin{array}{c}\text { allophane, hydrated } \\
\text { halloysite } \\
\text { (only } \mathrm{A}(\mathrm{II}) \text { ) }\end{array}$} \\
\hline
\end{tabular}


and cation exchange capacity of these clay samples are also shown in Table 3 . The method employed for determination of cation exchange capacity was Yoshida et al.'s method ${ }^{13}$ ) which is based on Schollenberger's method. That is to say, a clay sample was allowed to be saturated with ammonium. The ammonium was replaced by sodium cations using 10 percent sodium chloride solution and the amount of ammonium replaced was determined by the colorimeter. Water used is distilled water.

\section{(3) The Amount of Additives and the Curing Time of Specimens}

The cement contents selected are 10,20 and 30 percent by weight of dry clay mineral samples. The amounts of the $\mathrm{Ca}(\mathrm{OH})_{2}$ added are 3,6 and 9 percent by weight of dry clay minerals samples. Each experiment is carried out for specimens cured for $1,3,7,14,28,91,182$ and 364 days.

\section{(4) Procedure}

(a) Unconfined compression test

Air-dried minerals and cement are first mixed and followed by the addition of the distilled water and the subsequent mixing by hand until an uniform specimen is obtained. Cylindrical specimens, which are $5 \mathrm{~cm}$ in diameter and $10 \mathrm{~cm}$ high, are compacted statically by an oil jack so as to equal the optimum moisture content and maximum dry density of each clay-cement combination. Specimens sealed by paraffin wax are cured at $20^{\circ} \mathrm{C}$ under a 85 percent relative humidity. The loading speed at the compression test is $0.2 \mathrm{~kg} / \mathrm{cm}^{2} / \mathrm{sec}$.

(b) $\mathrm{pH}$ test

The $\mathrm{pH}$ value for each sample is the abration $\mathrm{pH}$, which was measured by a glass electrode $\mathrm{pH}$ meter (manufactured by Toadempakogyo Co.) for filtrate prepared by the following procedure:

Ten grams of the ground specimens to pass the $74 \mu$ sieve were mixed with $50 \mathrm{cc}$ distilled water with an electric stirrer for 10 minutes. The suspension was filtered immediately.

(c) X-ray diffraction

The samples ground in a mortar were examined by an X-ray diffractometer, "Geigerflex" of Rigakudenki Co., under the following measuring conditions.

For the purpose of identifying the reaction products: Target: Cu, Filter: Ni, Voltage : $30 \mathrm{kV}$, Current: $15 \mathrm{~mA}$, Scale factor: 2, Time constant: 8 Multiplier:0.8, Scanning speed $: 2 \% \mathrm{~min}$, Divergency slit : $1^{\circ}$, Scattering slit $: 1^{\circ}$, Receiving slit : 0.15 $\mathrm{mm}$, Chart speed : $2 \mathrm{~cm} / \mathrm{min}$.

For the purpose of measuring intesity of two alite belite peaks at $1.77 \AA$ and $2.20 \AA$ : Target : $\mathrm{Cu}$, Filter Ni, Voltage : $40 \mathrm{kV}$, Current : $15 \mathrm{~mA}$, Scale factor : 8, Time constant : 4, Multiplier : 1.0, Scanning speed : $0.5 / \mathrm{min}$., Divergcy slit : $2.5^{\circ}$, Scattering slit : $2.5^{\circ}$, Receiving slit $: 0.30 \mathrm{~mm}$, Chart speed $: 1 \mathrm{~cm} / \mathrm{min}$.

(d) Differential thermal analysis The same ground samples as those for X-ray diffraction were used for differential thermal analysis. A "Derivatograph', manufactured in Hungary, equipped with a single-unit platinum block with platinum-rhodium thermocouples was used at the heating rate, $10^{\circ} \mathrm{C} /$ min., with $1000 \mathrm{mg}$ sample. Calcined aluminum oxide was used as the reference material.

\section{RESULTS AND DISUSSIONS}

\section{FUNCTION OF THE $\mathrm{Ca}(\mathrm{OH})_{2}$ PROD- UCED BY THE CEMENT HYDRATI- ON IN CLAY-CEMENT MIXTURE}

\section{(1) X-ray Diffraction}

Fig. 1 and Fig. 2 indicate the X-ray diffraction diagrams of bentonite and kaolinite ( $\mathrm{Ka}(\mathrm{II}))$ $\mathrm{Ca}(\mathrm{OH})_{2}$ mixture, respectively.

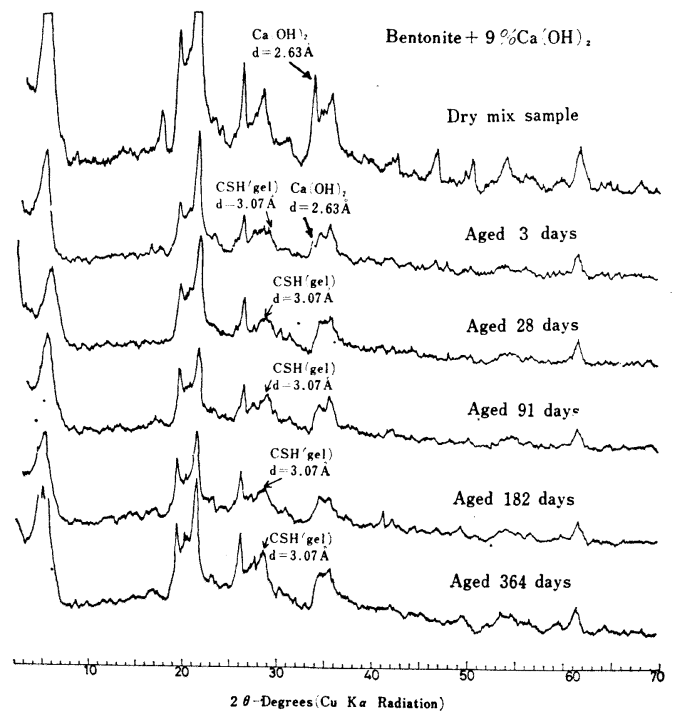

Fig. 1 X-ray diagrams for bentonite (MB)+ $9 \% \mathrm{Ca}(\mathrm{OH})_{2}$ samples cured for 3,28 , 91,182 and 364 days

Only both 9 and 6 percent $\mathrm{Ca}(\mathrm{OH})_{2}$ content samples at the curing time of 3 days indicate the $\mathrm{X}$-ray diffraction peak of $\mathrm{Ca}(\mathrm{OH})_{2}$ at $2.63 \AA$ (Fig. $3)$.

As reported by several investigators ${ }^{14), 15), 16), 17), 18)}$, a great amount of $\mathrm{CSH}$ (gel) is produced as a reaction product of the bentonite- $\mathrm{Ca}(\mathrm{OH})_{2}$ interaction. The formation of $\mathrm{CSH}$ (gel) is evinenced by two sharp peaks at $3.07 \AA$ and $2.08 \AA$ (Fig. 1). 


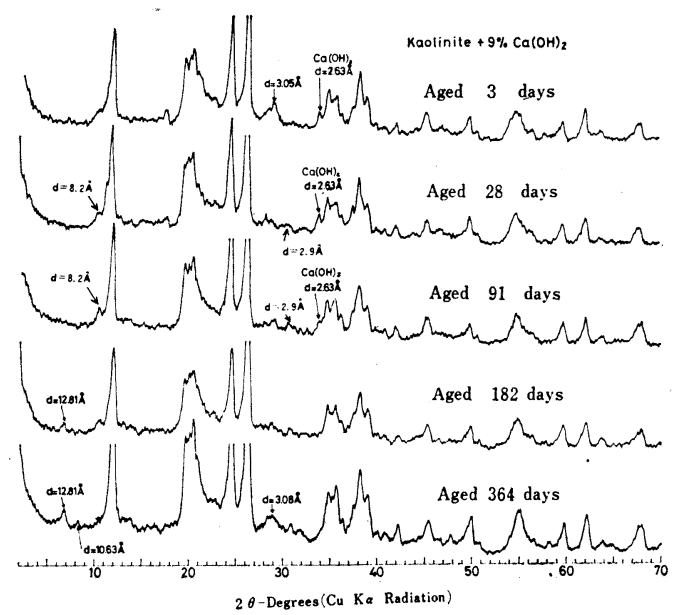

Fig. 2 X-ray diagrams for kaolinite $(\mathrm{Ka}(\mathrm{II}))+$ $9 \% \mathrm{Ca}(\mathrm{OH})_{2}$ samples cured for $3,28,91$, 182 and 364 days

However, the formation of calcium aluminate hydrate can not de finitely be confirmed.

The peak height of $\mathrm{Ca}(\mathrm{OH})_{2} \quad(d=2.63 \AA)$ in kaolinite- $\mathrm{Ca}(\mathrm{OH})_{2}$ mixtures rapidly decreases until 7 days of curing (Fig. 4). The comparison in the changes of the X-ray diffraction peak height between kaolinite-cement and $-\mathrm{Ca}(\mathrm{OH})_{2}$ mixtures (Fig. 5) apparently suggests that the liberation of $\mathrm{Ca}(\mathrm{OH})_{2}$ from the cement hydration and the kaolinite- $\mathrm{Ca}(\mathrm{OH})_{2}$ interaction simultaneously progress with curing time.

The peaks at 8.2 and $9.2 \AA$ are observed in 9 percent additive content sample of kaolinite- $\mathrm{Ca}(\mathrm{OH})_{2}$ at the end of $3,7,14,28$ and 91 days of curing (Fig. 2). These peaks may be considered to be the reflections of hillebrandite newly formed. They disappear in the 182 and 364 days curing sample, and a sharp peak is detected at $12.5 \AA$. This peak may probably be the basal reflection of $\mathrm{CSH}(\mathrm{I})$. This fact interpretes that hillebrandite of high lime-silica ratio is converted to the $\mathrm{CSH}(\mathrm{I})$ of the low one after the cure of 91 days. The formation of hillebrandite is evidencedby D.T.A. data as described below.

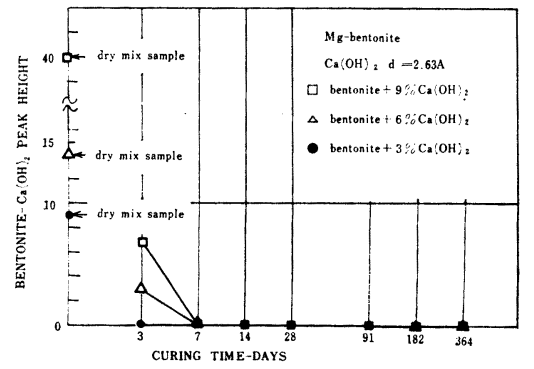

Fig. 3 X-ray diffraction peaks for hydrating bentonite $(\mathrm{MB})-\mathrm{Ca}(\mathrm{OH})_{2}$ mixtures

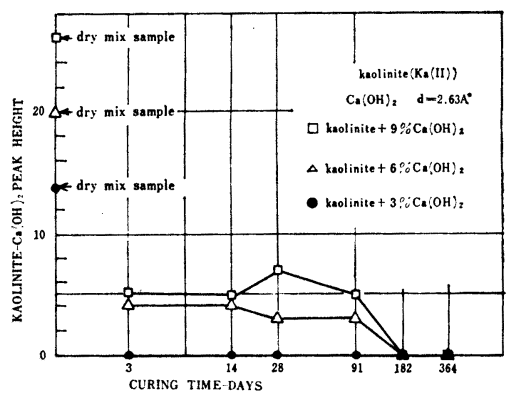

Fig. 4 X-ray diffraction peaks for hydrating kaolinite $(\mathrm{Ka}(\mathrm{II}))-\mathrm{Ca}(\mathrm{OH})_{2}$ mixtures

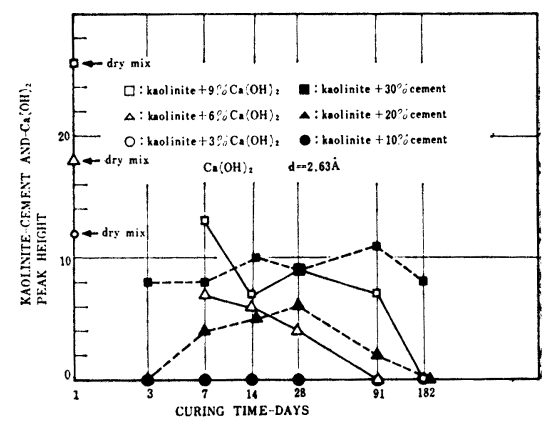

Fig. 5 X-ray diffraction peaks for hydrating kaolinite- $\mathrm{Ca}(\mathrm{OH})_{2}$ and cement mixtures
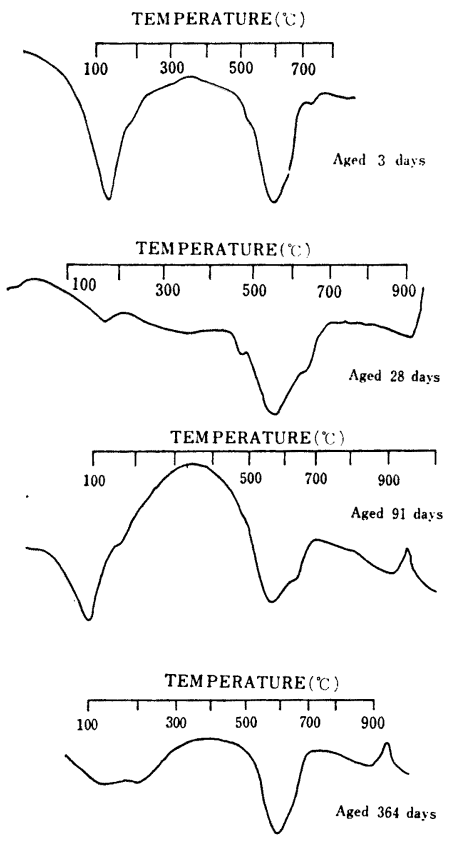

kaolinite $(\mathrm{Ka}(\mathrm{II}))+9 \% \mathrm{Ca}(\mathrm{OH})_{2}$

kaolinite $(\mathrm{Ka}(\mathrm{II}))+9 \% \mathrm{Ca}(\mathrm{OH})_{2}$

Fig. 6 D.T.A curves for kaolinite $(\mathrm{Ka}$ (II)) + $9 \% \mathrm{Ca}(\mathrm{OH})_{2}$ cured for $3,28,91$ and 364 days 
In this respect, it is mentioned that hillebrandite appears to be formed from the starting materials through the successive intermediate stages of $\mathrm{CSH}$ (II) or some other ill-crystallized material and $\alpha-\mathrm{C}_{2} \mathrm{~S}$ hydrate ${ }^{19)}$. The reaction seems to proceed through the following process : kaolinite- $\mathrm{Ca}(\mathrm{OH})_{2}$ mixture $\rightarrow$ illcrystallized $\mathrm{CSH}$ (with high lime-silica ratio) $\rightarrow$ hillebrandite $\rightarrow \mathrm{CSH}$ ( I ) (with low lime-silica ratio).

On the contrary, none of the X-ray diffraction data of kaolinite-cement shows the presence of hillebrandite and $\operatorname{CSH}(\mathrm{I})$.

\section{(2) Differential Thermal Analysis}

The endothermic bulge at about $180^{\circ} \mathrm{C}$ exists in all of D.T.A. curves of kaolinite- $\mathrm{Ca}(\mathrm{OH})_{2}$ mixtures with 9 percent $\mathrm{Ca}(\mathrm{OH})_{2}$ content, as in kaolinite-cement mixtures (Fig. 6). This peak belongs to the tetracalcium aluminate hydrate. There is another endotherm at about $630^{\circ} \mathrm{C}$ in the 28 and 91 days of curing samples as well. This peak can be resposible for the dehydroxylation of hillebrandite. However, no bulge can be found at about $630^{\circ} \mathrm{C}$ in the D.T. A. curve of 364 days curing samples. Thus, nonexistence of hillebrandite in the 364 days curing sample evidenced by D.T.A. agrees with the X-ray diffraction tests result described above. The D.T.A. curves of kaolinite-cement with 30 percent cement content until 28 days of curing show a very faint endothermic deflection at about $630^{\circ} \mathrm{C}$, which disappear after 91 days of curing (Fig. 7).

An endothermic bulge due to $\mathrm{Ca}(\mathrm{OH})_{2}$ at about $500^{\circ} \mathrm{C}$ in kaolinite- $\mathrm{Ca}(\mathrm{OH})_{2}$ has disappeared at 91 days age, although that in kaolinite-cement can be detectedeven at 364 days ages (Fig. 7). This fact demonstrates that the amount of $\mathrm{Ca}(\mathrm{OH})_{2}$ which is consumed by the interaction with kaolinite in the kaolinite-cement is less than that in the kaolinite-

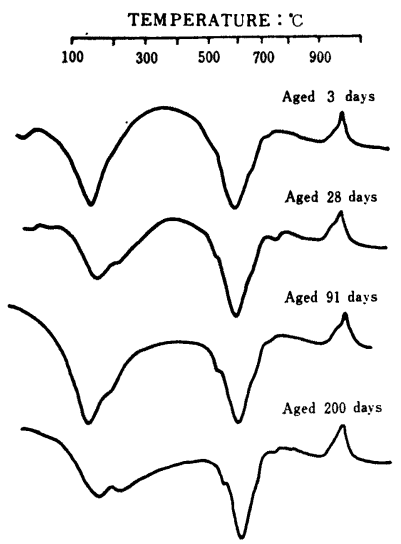

$$
\text { Kaol inite }+30 \text { ? i cement }
$$

Fig. 7 D.T.A. curves for kaolinite $+30 \%$ cement samples for $3,28,91$ and 200 days
$\mathrm{Ca}(\mathrm{OH})_{2}$ mixture. It is much interesting to note that the apparent endothermic bulge due to hillebrandite exists in the kaolinite- $\mathrm{Ca}(\mathrm{OH})_{2}$ mixture consuming far more $\mathrm{Ca}(\mathrm{OH})_{2}$ than the kaolinitecement mixture.

\section{(3) pH Test}

The $\mathrm{pH}$ changes with curing time in the bentonite- $\mathrm{Ca}(\mathrm{OH})_{2}$ mixtures are presented in Fig. 8. As shown in the figure, the $\mathrm{pH}$ in bentonite- $\mathrm{Ca}(\mathrm{OH})_{2}$ mixtures with 6 and 9 percent $\mathrm{Ca}(\mathrm{OH})_{2}$ content rapidly decreases after 3 and 7 days of curing, respectively. The 3 percent $\mathrm{Ca}(\mathrm{OH})_{2}$ content sample shows the $\mathrm{pH}$ value of about 11.10 at 3 days ages, followed by little change with curing time, This tendency of the $\mathrm{pH}$ changes in bentonite- $\mathrm{Ca}(\mathrm{OH})_{2}$ is different from that in bentonite-cement (Fig. 8, Fig. 9). Thus, the comparison in the $\mathrm{pH}$ changes between these two different mixtures indicates that little pozzolanic reaction occurs in bentonite$\mathrm{Ca}(\mathrm{OH})_{2}$ mixtures with 3 percent $\mathrm{Ca}(\mathrm{OH})_{2}$ content. Furthermore, the reduction in $\mathrm{pH}$ of the bentonitecement with 10 percent cement content is found to

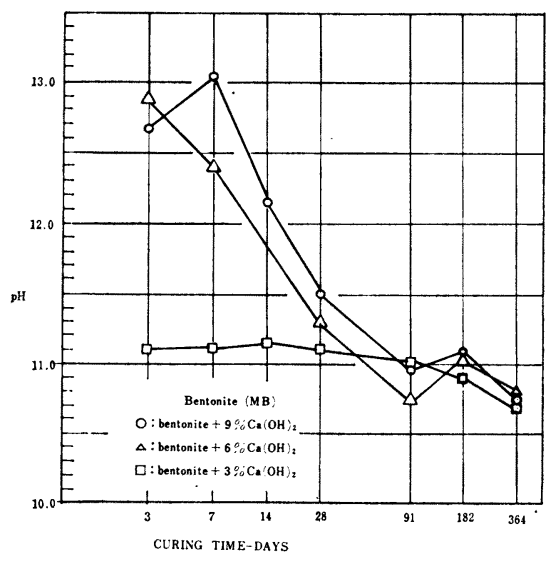

Fig. 8 pH changes of bentonite- $\mathrm{Ca}(\mathrm{OH})_{2}$ mixtures with curing time

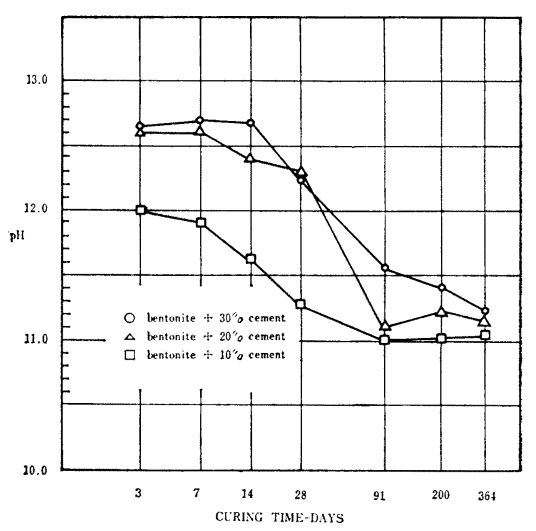

Fig. $9 \mathrm{pH}$ changes of bentonite-cement mixtures with curing time 


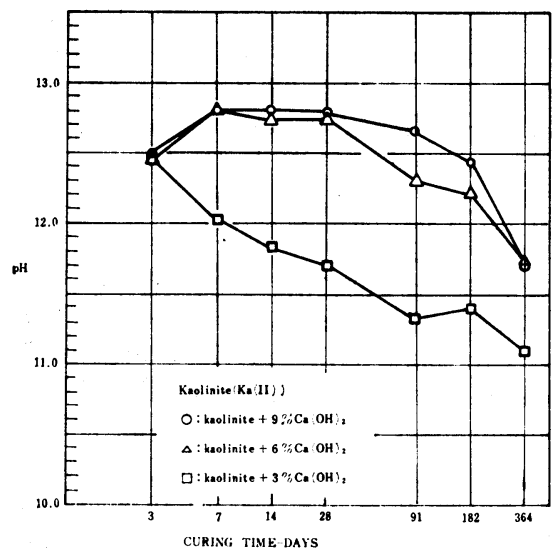

Fig. $10 \mathrm{pH}$ changes of kaolinite- $\mathrm{Ca}(\mathrm{OH})_{2}$ mixtures with curing time

be not due to the pozzolanic reaction. This conclusion agrees with that drawn by the detailed discussion on the $\mathrm{pH}$ changes and unconfined compression test results in bentonite-cement mixtures ${ }^{7}$.

The reduction in the value of the kaolinite$\mathrm{Ca}(\mathrm{OH})_{2}$ with curing time is greater than that of the kaolinite-cement (Fig. 10, Fig. 9).

\section{(4) Unconfined Compression Test}

The unconfined compressive strength of kaolinite $(\mathrm{Ka}(\mathrm{II}))-\mathrm{Ca}(\mathrm{OH})_{2}$ and bentonite- $\mathrm{Ca}(\mathrm{OH})_{2}$ specimens increases with the lapse of curing time, as shown in Fig. 11 and Fig. 12. Little difference in the strength of kaolinite- $\mathrm{Ca}(\mathrm{OH})_{2}$ at 3 and 7 days curing is found between different concentrations of the additive (Fig. 11). The strength of kaolinite $(\mathrm{Ka}(\mathrm{II}))-\mathrm{Ca}(\mathrm{OH})_{2}$ mixture at the end of 28 days of curing decreases, as the amount of the additive increases. The compressive strength of the specimen with 3 percent $\mathrm{Ca}(\mathrm{OH})_{2}$ increases a little after 28 days of curing. At the long-term curing of 91,182 and 364 days, the kaolinite 6 percent $\mathrm{Ca}(\mathrm{OH})_{2}$ specimens have the greatest strength of all. The calcium hydroxide of 3 percent by weight of clay may be almost consumed by the pozzolanic reaction

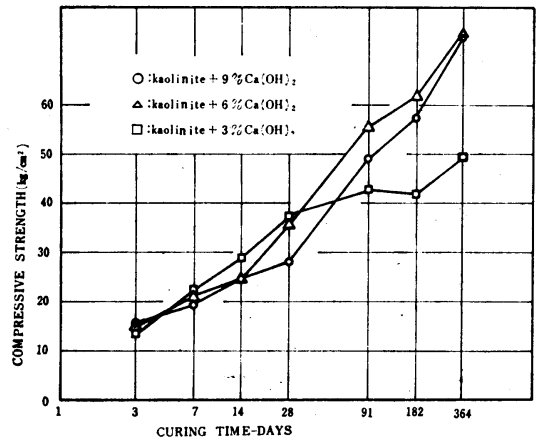

Fig. 11 Variation in strength with curing time

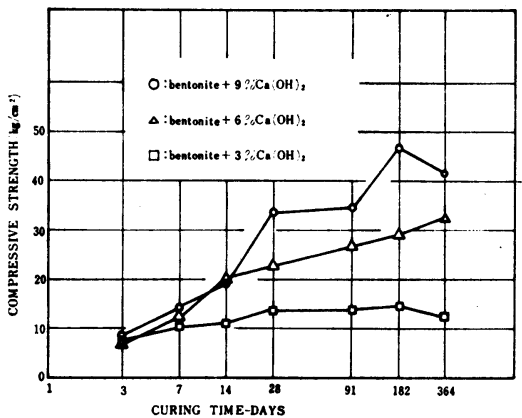

Fig. 12 Variation in strength with curing time

contributing to the strength development before 91 days of curing.

On the contrary, only a little development of strength is observed in the bentonite- $\mathrm{Ca}(\mathrm{OH})_{2}$ mixture with 3 percent additive. Further, there is a considerable difference in the compressive strength between concentrations of the additive at 28, 91, 182 and 364 days of curing. Thus, as stated by Eades and $\mathrm{Grim}^{19)}$, it can be concluded that the strength of bentonite-cement is not developed without adding the $\mathrm{Ca}(\mathrm{OH})_{2}$ beyond the amount required to attain the lime retention point obtained from strength tests. The three curves in Fig. 12

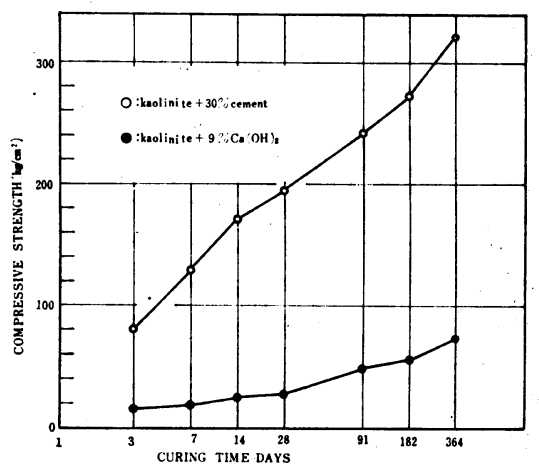

Fig. 13 Variation in strength with curing time

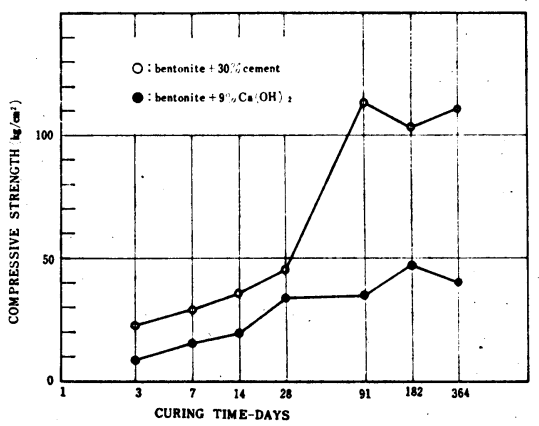

Fig. 14 Variation in strength with curing time 
show that a little or no increase in strength with curing time is found after all of $\mathrm{Ca}(\mathrm{OH})_{2}$ added have been consumed by the pozzolanic reaction.

Plots of the unconfined compressive strength against curing time in clay-cement and $-\mathrm{Ca}(\mathrm{OH})_{2}$ specimens are given in Fig. 13 and Fig. 14. These pair of curves are comparable one another in their additive concentration. The two curves in the combination of bentonite-cement and $-\mathrm{Ca}(\mathrm{OH})_{2}$ mixtu res show that there is a little difference in strength between them at the initial stage of curing, followed by a great difference at the long-term curing (91, 182 and 364 days of curing). The long-term development of strength in the bentonite-cement is considered to be due to the pozzolanic reaction of bentonite with $\mathrm{Ca}(\mathrm{OH})_{2}$ generated by the cement hydration, as previously concluded by the authors ${ }^{7)}$. Therefore, such dissimilarity in the tendency of the strength development between bentonitecement and $-\mathrm{Ca}(\mathrm{OH})_{2}$ could be responsible for the difference between the $\mathrm{Ca}(\mathrm{OH})_{2}$ of reagent and the one liberated by the cement hydration $^{20)}$. As another aspect, it could be attributed to the difference in the properties of calcium silicate hydrate formed under considerably different environments between clay-cement and $-\mathrm{Ca}(\mathrm{OH})_{2}$ mixtures. In fact, different reaction products are formed between the kaolinite-cement and- $\mathrm{Ca}(\mathrm{OH})_{2}$ mixtures, as shown by the X-ray diffraction test results. Furthermore, the effect of anhydrous cement particles on the strength can not be out of consideration.

\section{HYDRATION OF ALITE AND BELITE IN COMPACTED CLAY-CEMENT MIX- TURES The Influence of Types of Cement (High-Early-Strength and Moderate-Heat Cement) on the Clay Minerals-Cement Interaction}

\section{(1) X-ray Diffraction}

In general, the alite and belite X-ray diffraction patterns overlap each other so that there is no usable peak of one of these materials which is not interfered with by a peak of the other. The rate of the hydration of alite and belite in clay-cement mixtures can be determined based on Kantro et al's method for the determination of the major compound contents of portland cements by X-ray diffraction ${ }^{21)}$. The diffraction peaks selected for the analysis are those at $1.77 \AA$ and $2.20 \AA$.

The ratio of weight of alite and belite in claycement and cement paste after a certain curing time to that in dry mix samples is plotted as shown in Fig. 15 and Fig. 16. It may be seen from these

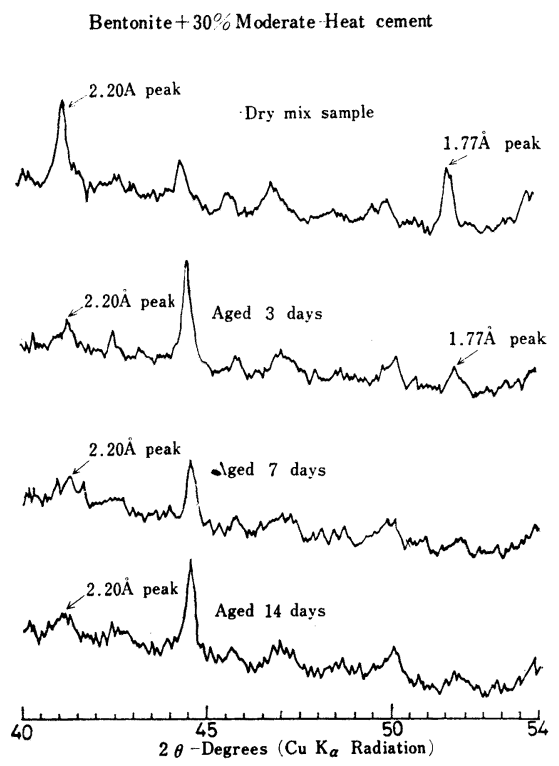

Fig. 15 Reduction rate in the quantity of alite and belite in kaolinite ( $\mathrm{Ka}(\mathrm{III}))$-and bentonite (MB)-30\% high-early-strength cement mixtures

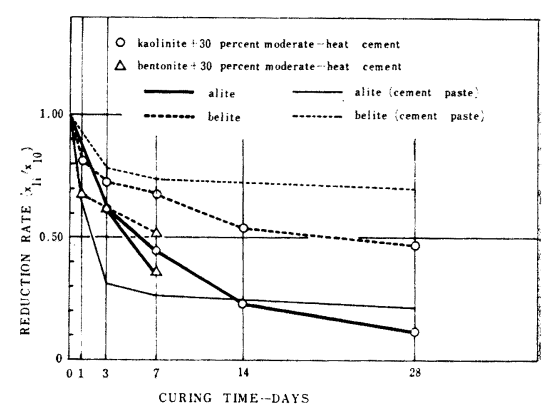

Fig. 16 Reduction rate in the quantity of alite and belite in kaolinite ( $\mathrm{Ka}$ (III)-and bentonite (MB)-30\% moderate-heat. cement mixtures

figures that, in the initial stage of hydration (within 7 days of curing), the reduction rate in the quantity of alite in both kaolinite $(\mathrm{Ka}(\mathrm{III})$ )-cement mixtures is less than in cement paste. However, the amount of alite in cement paste decreases a little or little after the initial hydration (from 1 to 7 days of curing), while that in kaolinite-cement mixtures continues gradually to decrease with curing time.

The hydration of belite in the kaolinite- and bentonite-moderate-heat cement mixtures appears to proceed faster than in cement paste (Fig. 16). Within 7 days of curing, the hydration of alite in bentonite-cement mixtures takes place more slowly than in cement paste. However, rapid hydration after 7 days of curing results in the early disappe- 

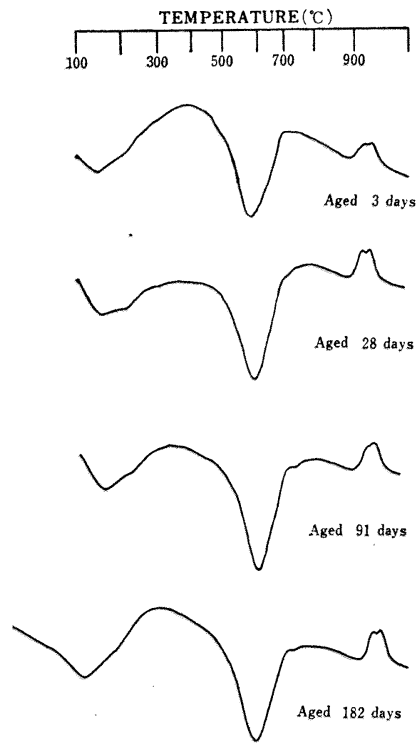

Kaolinte:Ka:III) $y+30^{\circ} \%$ high-early-strength cement

Fig. 17 D.T.A. curves for kaolinite $+30 \%$ high-early-strength cement samples cured for $3,28,91$ and 182 days
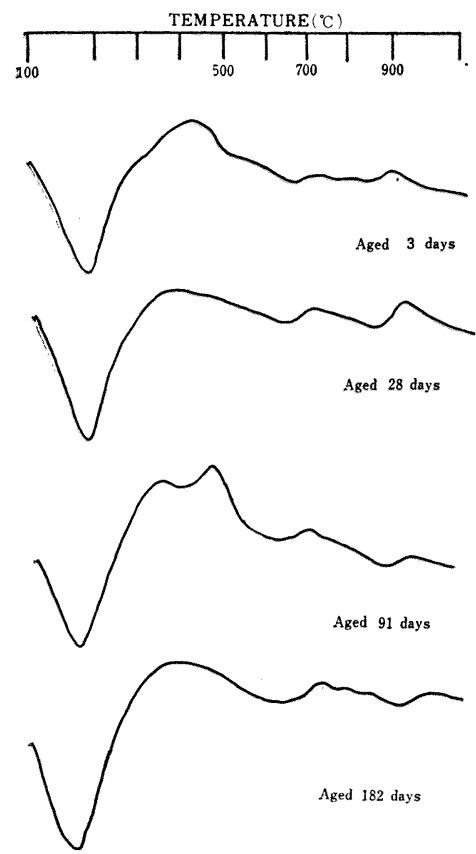

Fig. 19 D.T.A. curves for bentonite $+30 \%$ high-early-strength cement samples cured for $3,28,91$ and 182 days
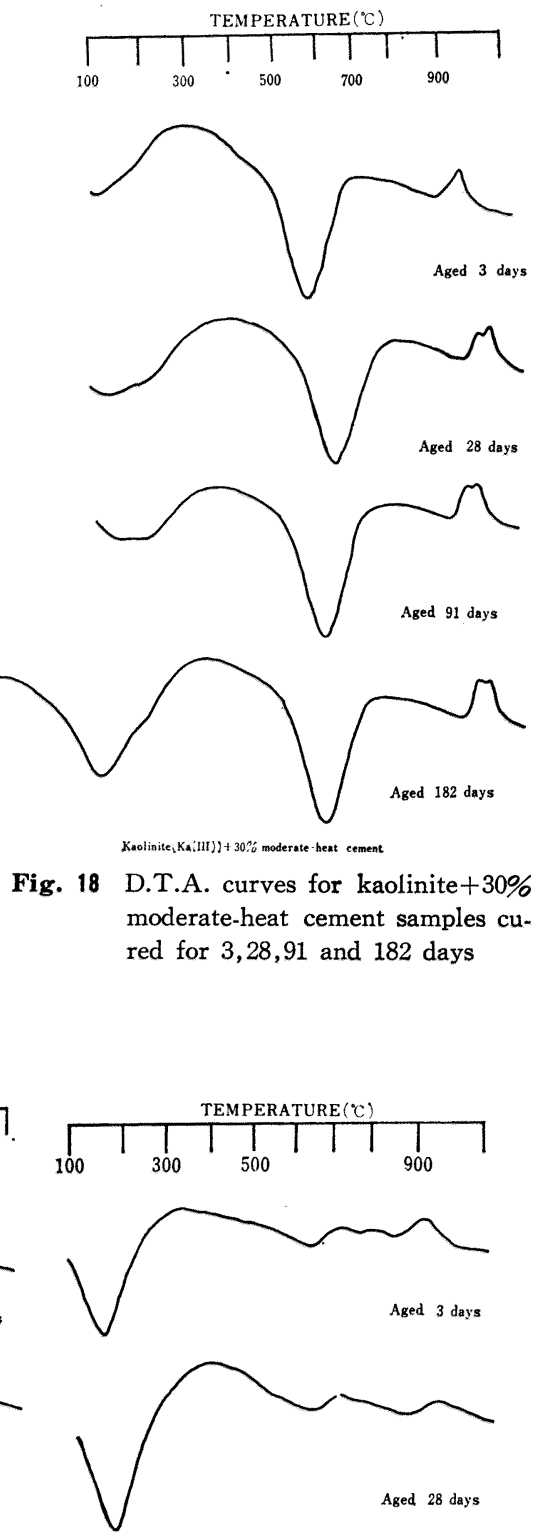

Fig. 18 D.T.A. curves for kaolinite $+30 \%$ moderate-heat cement samples cured for $3,28,91$ and 182 days
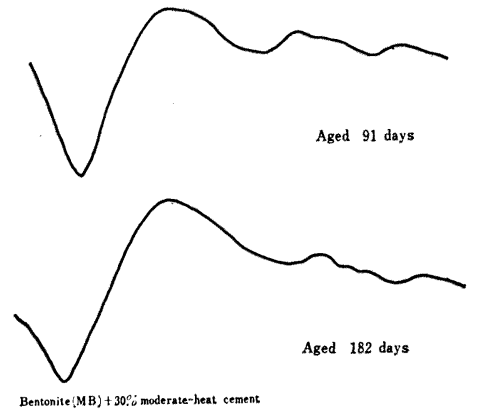

Fig. 20 D.T.A curves for bentonite $+30 \%$ moderate-heat cement samples cured for 3,28 , 91 and 182 days arance of the peak at $1.77 \AA$. None of the bentonite-cement mixtures shows the $1.77 \AA$ peak at 14 days of curing

\section{(2) Differential Thermal}

\section{Analysis}

The D.T.A. curves of kaolinite $(\mathrm{Ka}(\mathrm{III}))$ - and bentonite-cement mixtures using two types of cements are presented in Fig. 17, Fig. 18, Fig. 19 and Fig. 20.

There is no endotherm due to the dehydroxlation of $\mathrm{Ca}(\mathrm{OH})_{2}$ in all D.T.A. curves of kaolinite-cement. This fact disagrees with the results previously obtained by the authors ${ }^{7}$.

This discrepancy must be attributed to the difference between the amount of clay and silt fraction included in kaolinite clay sample used $(\mathrm{Ka}(I)$ and $\mathrm{Ka}(\mathrm{III})$ ) (see Table 1). That is to say, the kaolinite sample used in this investigation includes far more clay and silt fraction than that in the specimen made in our previous investigation ${ }^{7}$. The D.T.A. curve of the bentonite-moderateheat cement mixtures at 3 days ages has a comparatively large exothermic peak at about $900^{\circ} \mathrm{C}$, followed by a gradual decrease in its height with curing time (Fig. 20). On the other hand, the height of this peak in the bentonite-high-early-strength cement mixture increases during 3 to 28 days of curing (Fig. 19). The long-term curing samples (91 and 182 days curing) have no peak at about $900^{\circ} \mathrm{C}$ in both bentonite-cement mixtures (Fig. 19, Fig. 20). From these changes in D.T.A. curves with curing time, the following conclusion can be drawn:

Calcium silicate hydrate with low lime-silica ratio may be produced until 28 days of curing in the bentonite-cement mixtures to transform to the one with high lime-silica ratio at least after 91 days of curing, because, the 0.8 to $1.33 \mathrm{CaO} / \mathrm{SiO}_{2}$ hydrate gene- 
rally exhibits a strong exothermic effect in D.T.A. at $835^{\circ} \mathrm{C}$ to $900^{\circ} \mathrm{C}$, but the 1.5 to $2.0 \mathrm{CaO} / \mathrm{SiO}_{2}$ one no such exotherm ${ }^{22}$.

\section{(3) $\mathrm{pH}$ Test}

The $\mathrm{pH}$ in kaolinite- and bentonite-cement mixtures using two types of cement changes with curing time as shown in Fig.21 and Fig. 22.

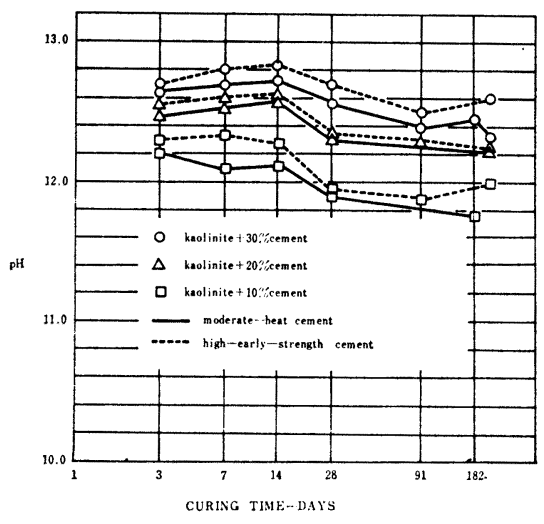

Fig. $21 \mathrm{pH}$ changes of kaolinite-cement mixtures with curing time

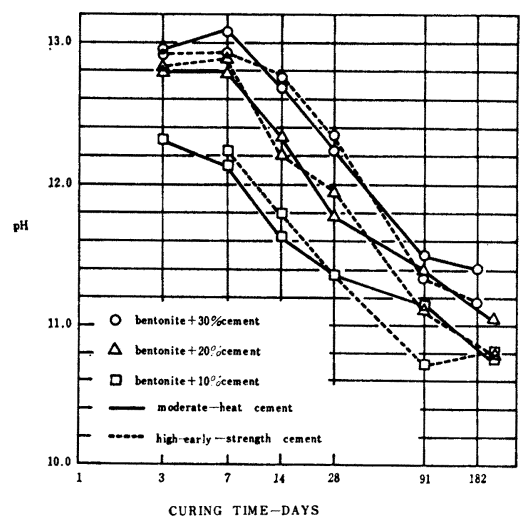

Fig. $22 \mathrm{pH}$ changes of bentonite-cement with curing time

The $\mathrm{pH}$ of the kaolinite-cement mixtures using high-early-strength cement is higher than that of the ones with moderate-heat cement at all ages. The rapid reduction in the $\mathrm{pH}$ value is found in the bentonite-cement mixtures (Fig. 22). The pH value of the bentonite-moderate-heat-cement mixtures at the long-term (91 and 182 days) is higher than that of the bentonite-high-early-strength cement, although the relationship between both of them at ages up to 28 days does not indicate a definite tendency. This phenomena could be interpreted by the presence of a greater amount of anhydrous $\beta \mathrm{C}_{2} \mathrm{~S}$ in the bentonite-moderate-heat cement than in the bentonite-high-early-strength cement. That is to say, hydrolysis of such a greater amount of $\beta \mathrm{C}_{2} \mathrm{~S}$ rema- ining in the bentonite-moderate-heat-cement at the end of the long-term curing takes place in the course of the preparation of the filtrate for the $\mathrm{pH}$ measurement, raising the $\mathrm{pH}$ of them. The amount of lime liberated by hydrolysis of the $\mathrm{C}_{3} \mathrm{~S}$ and $\mathrm{C}_{3} \mathrm{~A}$ is greater than that liberated by the other compounds (which includes also $\beta \mathrm{C}_{2} \mathrm{~S}, \gamma \mathrm{C}_{2} \mathrm{~S}, \mathrm{C}_{5} \mathrm{~A}_{3}$ and $\mathrm{C}_{2} \mathrm{~F}$ ), even though the total amount of lime present in the system was the same in each case $^{23}$. Therefore, the degree of the effect of the compounds in clay mineral-cement mixture on the $\mathrm{pH}$ value is great in the order of $\mathrm{Ca}(\mathrm{OH})_{2}, \mathrm{C}_{3} \mathrm{~S}$, and $\beta \mathrm{C}_{2} \mathrm{~S}$, if the $\mathrm{Ca}(\mathrm{OH})_{2}$ exists in the mixture.

The difference between the $\mathrm{pH}$ of kaolinite-moderate-heat and high-early-strength-cement at all age$\mathrm{s}$ until 182 days may probably be due to the difference between the amount of $\mathrm{Ca}(\mathrm{OH})_{2}$ present in those mixtures.

\section{(4) Unconfined Compression Test}

The strength increase with curing time in kaolinite $(\mathrm{Ka}(\mathrm{III}))$ - and bentonite-cement using two types of cement is shown in Fig. 23 for 30 percent cement content specimens. The compressive strength of cement mortars which is obtained based on JIS R 5201, is also plotted against each curing time.

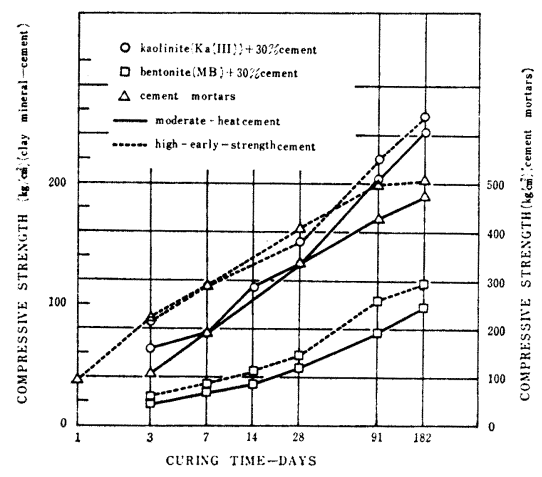

Fig. 23 Variation in strength with curing time

As stated in general, the high-early-strength cement mortars exhibit relatively high strength at the ages up to 91 days, but thereafter the difference between the strength of clay minerals-high-earlystrength cement and moderate-heat cement mixtures decreases with curing time, becoming only a little at the end of 182 days of curing.

Both types of the kaolinite-cement mixtures gain strength at the greater rate than cement mortars after 28 days of curing. In the kaolinite-cement mixtures, the strength of high-early-strength cement is considerably higher than that of moderate-heat cement at the ages up to 28 days, but after that there exists only a little difference between them. 
However, remarkably peculiar tendency is found in the strength development of the bentonite-cement mixtures. That is to say, a little or little difference between the compressive strength of bentonite-highearly-strength and moderate-heat cement at early curing periods until 28 days is followed by a gradualy increasing difference between them. This is the tendency completely reverse to that in kaolinitecement and cement mortars.

Since the compressive strength of the bentonitecement greatly depends upon the interaction between bentonite and $\mathrm{Ca}(\mathrm{OH})_{2}$ liberated from hydrating cement, the quantity of $\mathrm{Ca}(\mathrm{OH})_{2}$ available for such interaction should be a significant factor affecting the strength development. Therefore, a relatively less increase in the strength of bentonitemoderate-heat cement mixtures during the longterm curing may be due to the liberation of less $\mathrm{Ca}(\mathrm{OH})_{2}$. The causes for the formation of less $\mathrm{Ca}(\mathrm{OH})_{2}$ in bentonite-moderate-heat cement are as follows :

The $\beta \mathrm{C}_{2} \mathrm{~S}$ produces much less $\mathrm{Ca}(\mathrm{OH})_{2}$ than $\mathrm{C}_{3} \mathrm{~S}$ because of the lower $\mathrm{Ca} / \mathrm{Si}$ ratio of the starting material. Furthermore, much $\beta \mathrm{C}_{2} \mathrm{~S}$ remains even after 91 and 182 days, as indicated by the higher $\mathrm{pH}$ in bentonite-moderate-heat cement than in bentonite-high-early-strength cement at these ages.

\section{CHARACTERISTIC PHENOMENA IN SEVERAL CLAY MINERALS-CEMENT INTERACTION}

\section{A. Chlorite-vermiculite mixed-layer mineral- cement mixture}

\section{(1) X-ray Diffraction}

Fig. 24 shows the X-ray diffraction data of mixed-layer mineral-cement mixtures. Fig. 25 indicates the reduction of the X-ray diffraction peak height of alite and belite at $2.76 \AA$ with curing time. This tendency is not much different from that in bentonite-, kaolinite- and sericite-cement mixtures, which was described in our previous report ${ }^{7}$. The very high $\mathrm{Ca}(\mathrm{OH})_{2}$ peak appears in most samples; even in 10 percent cement content samples, a sharp peak at $2.63 \AA$ is found at the cure of 7,14 and 28 days (Fig. 26). The long-term curing samples with 30 percent cement content have the broad peak covering the range of 3.20 to $3.07 \AA$. The basal reflection of this mineral weakens with increasing curing time (Fig. 24). A sharp peak at $10 \AA$ exists in the $\mathrm{X}$-ray diffraction diagrams of 182 and 364 days curing samples with 30 and 20 percent cement content. This peak strengthens with curing time to become considerably large at the 364 days age.

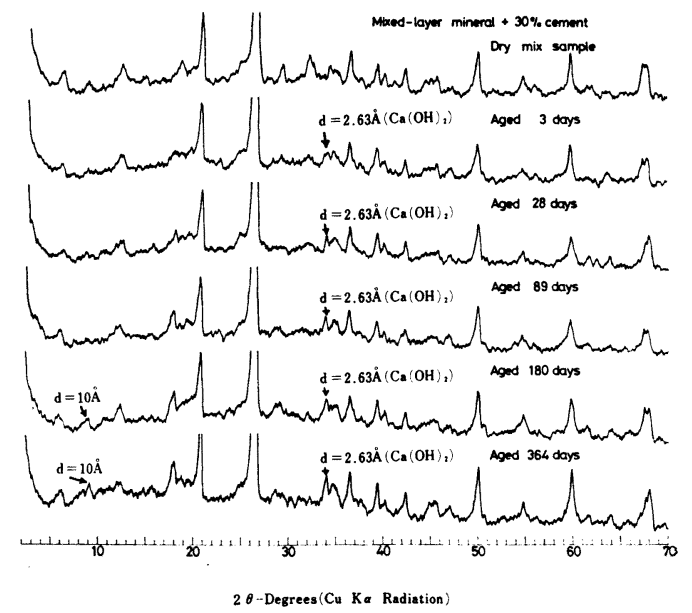

Fig. 24 X-ray diagrams for mixed-layer mineral $+30 \%$ cement samples cured for 3,28 , 89,180 and 394 days

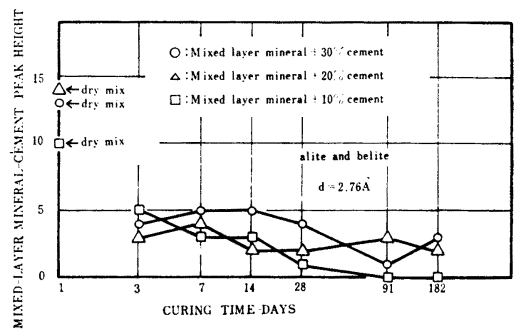

Fig. 25 X-ray diffraction peaks for hydrating mixed-layer miueral cement mixture

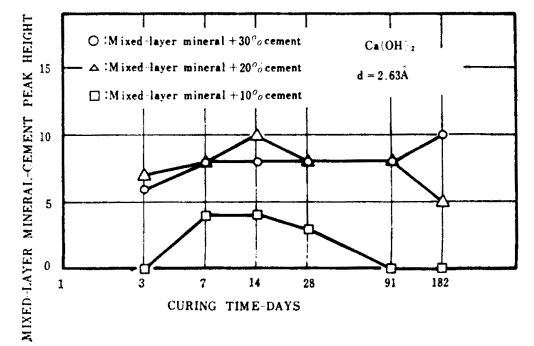

Fig. 26 X-ray diffraction peaks for hydrating mixed-layer mineral-cement mixture

It may be a X-ray diffraction peak of a certain magnesium silicate hydrate, judging from the ASTM's powder diffraction file and from other experimantal results such as $\mathrm{pH}$ test and unconfined compression test results described below.

\section{(2) Differential Thermal Analysis}

The D.T.A. curves of mixed-layer mineral-cement mixtures are presented in Fig. 27. As expected from the X-ray diffraction results, all curves except 3 days curing one exhibit a large peak at about $500^{\circ} \mathrm{C}$ responsible for the dehydroxylation of $\mathrm{Ca}$ $(\mathrm{OH})_{2}$. Further, the peak still remains without 


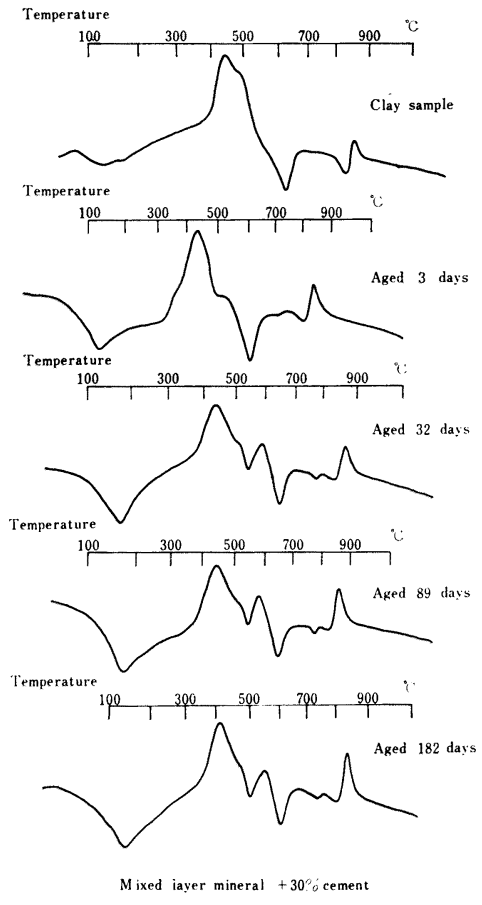

Fig. 27 D.T.A. curves for mixed-layer mineral $+30 \%$ cement cured for $3,32,89$ and 182 days

change in its size at the end of 182 days curing.

An endotherm at about $780^{\circ} \mathrm{C}$ found in the D.T. A. curves of 91 and 182 days curing sample may be due to either the calcium silicate hydrate with high $\mathrm{CaO} / \mathrm{SiO}_{2}$ ratio such as $r \mathrm{C}_{2} \mathrm{~S}$ hydrate or to the calcium carbonate.

\section{(3) pH test}

As easily expected from other test results, little changes in $\mathrm{pH}$ with curing time are found in the mixed-layer mineral-cement mixtures (Fig. 28). This fact gives an evidence for the inactivity in the pozzolanic reaction in these clay-cement samples.

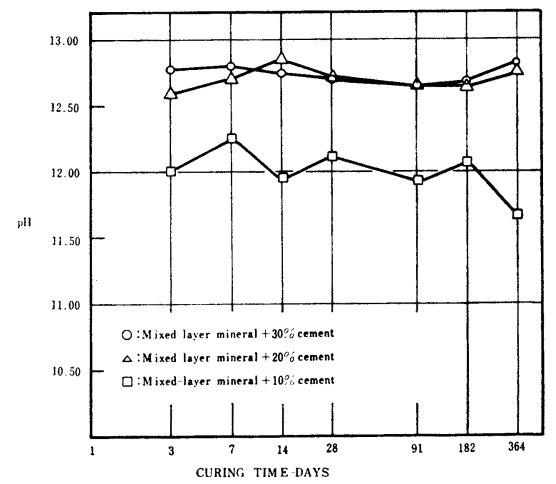

Fig. $28 \mathrm{pH}$ changes of mixed-layer mineralcement mixture with curing time

\section{(4) Unconfined Compression Tests}

It is very interesting that the strength of this clay-cement mixture greatly increase between 182 and 364 days of curing (Fig. 29). Such a great increase in strength after the cure of 182 days is not found in other clay mineral-cement mixtures. In this respect, little or no changes in the X-ray diffraction peak height of $\mathrm{Ca}(\mathrm{OH})_{2}$ and in the $\mathrm{pH}$ value between both curing times definitely demonstrate that the rapid strength increase is not caused by the pozzolanic reaction between the clay mineral and $\mathrm{Ca}(\mathrm{OH})_{2}$.

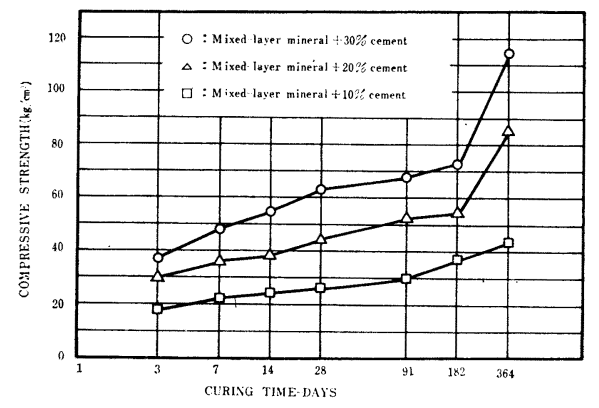

Fig. 29 Variation of compressive strength with curing time in mixed-layer mineral-cement mixture

Concerning the mineralogical properties of this clay mineral, Sugiura reported as follows ${ }^{24)}$ : “Generally, discussion on the diffraction lines at 1.50 to $1.54 \AA$ corresponding to the $(060)$ reflection can lead to the determination of the characteristics of the structural layer constituting a clay mineral. When primarily aluminum is present in the octahedral layer within the structure, this reflection appears at about $1.50 \AA$. When the major cation in the octahedral layer is magnesium, it does at about 1.54 $\AA$. This mineral is found to belong to the latter, that is, to a trioctahedral mineral, since the reflection in the randomly oriented specimen of this sample takes place at $1.537 \AA$ ',. It is found that this clay sample used includes chlorite-vermiculite mixed-layer mineral rich in magnesium as the predominant component (Table 3). Therefore, this clay mineral particles are presumed to be attacked at the edges under the alkaline environment to dissociate magnesia as well as silica and alumina. Consequently, in this clay-cement, a physicochemical reaction process in which magnesium is concerned should be expected to occur in addition to the pozzolanic reaction taking place in the mixture of cement and clay mineral having no brucite layer in its structure.

Two possible processes could be considered. The one is the substitution of silicon by magnesium in the 
tobermorite lattice, and the other a certain reaction process through which the chrysotile-like magnesium sillicate hydrate is formed. This chrysotile $(3 \mathrm{MgO}$. $2 \mathrm{SiO}_{2} \cdot 2 \mathrm{H}_{2} \mathrm{O}$ ), a mineral with a layer lattice, which is known to be fibrous in habit, is said to favor the strength development of cement paste ${ }^{25)}$. As stated previously, a new sharp X-ray diffraction peak at $10 \AA$ may suggest the likelihood of the later.

\section{B. Allophane $(\mathbf{A}(\mathbf{I}), \mathbf{A}(\mathbf{I I}))$-cement mixtures}

\section{(1) X-ray Diffraction}

Fig. 30, Fig. 31 and Fig. 32, Fig. 33 show the $\mathrm{X}$-ray diffraction diagram and the change in the peak height of alite and belite at $2.76 \AA$, respectively. Little change with curing time is found in the peak height of allophane $(\mathrm{A}(\mathrm{I}))$-cement at $2.76 \AA$, but the slow decrease in that of allophane (A(II))-cement. This fact shows that allophane suppresses the cement hydration. However, no suppression of the cement hydration occurs in the clay-cement mixtures using the allophane including the crystalline hydrated halloysite. That is to say, such a small amount of the crystalline inclusion in

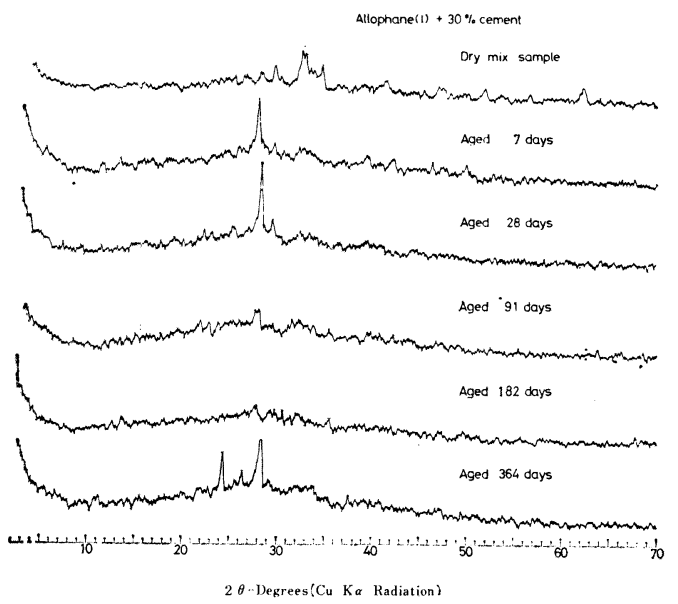

Fig. 30 X-ray diagrams for allophane ( I ) $+30 \%$ cement samples cured for $7,28,91,182$ and 364 days

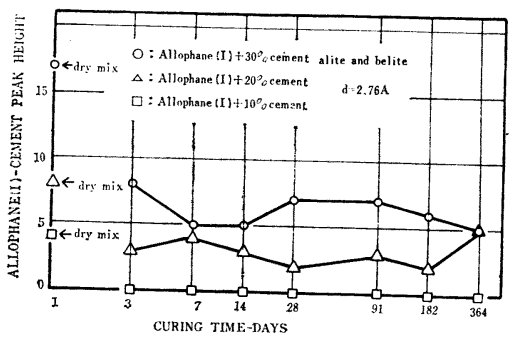

Fig. 31 X-ray diffraction peaks for hydrating allophane ( I )-cement mixture

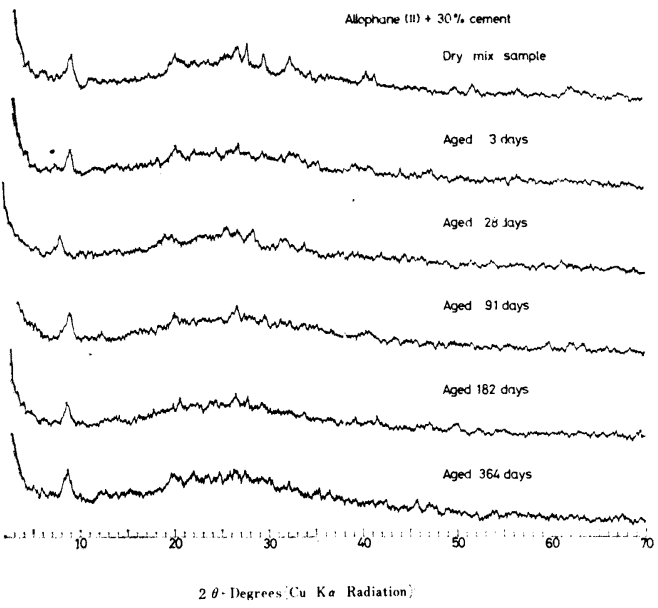

Fig. 32 X-ray diagrams for allophane (II) $+30 \%$ cement samples cured for $3,28,91,182$ and 364 days

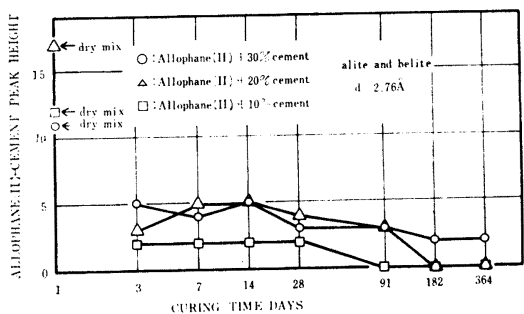

Fig. 33 X-ray diffraction peaks for hydrating allophane (II)-cement mixture

the amorphous allophane greatly affects the cement hydration in the compacted clay-cement mixture.

No X-ray diffraction peaks of the reaction products such as $\mathrm{Ca}(\mathrm{OH})_{2}, \mathrm{CSH}$ (gel) and calcium aluminate hydrate are found.

\section{(2) Differential Thermal Analysis}

D.T.A. curves of allophane (A(I ))-cement are presented in Fig. 34. These are almost the same as that of allophane clay mineral sample, indicating no progress of cement hydration in this clay-cement.

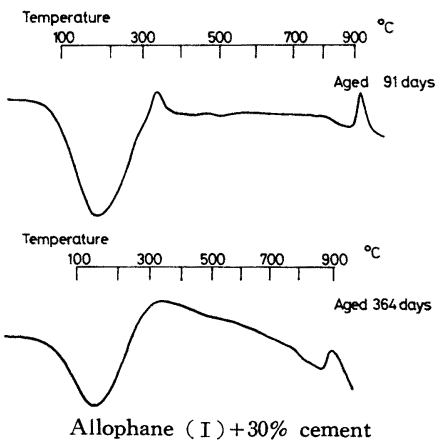

Fig. 34 D.T.A. curves for allophane ( I ) $+30 \%$ cement cured for 91 and 364 days 


\section{(3) pH Test}

As easily expected from other test results, a little changes in $\mathrm{pH}$ with curing time are found in the allophane (A(I), A(II))-cement (Fig. 35, Fig. 36). Such a slow decrease in $\mathrm{pH}$ with ages suggests a slow progress of the cement hydration in these clay-cement mixtures.

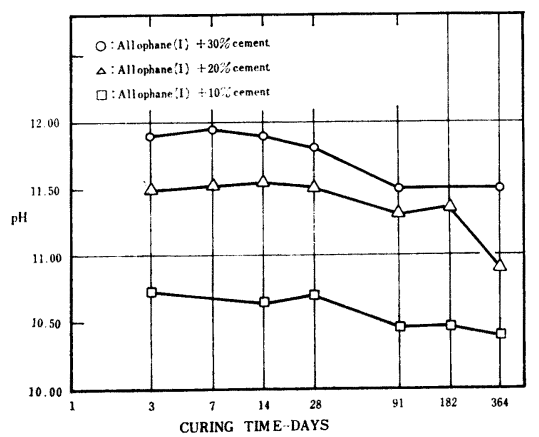

Fig. $35 \mathrm{pH}$ changes of allophane ( I )-cement mixture with curing time

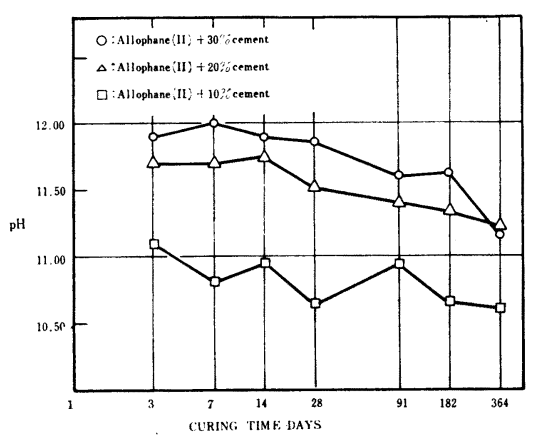

Fig. $36 \mathrm{pH}$ changes of allophane (II)-cement mixture with curing time

\section{(4) Unconfined Compression Test}

No strength development accompanying the progress of curing time is found in allophane $(A(I))$ -cement with 10 and 20 percent cement content; even in 30 percent cement content specimens, only

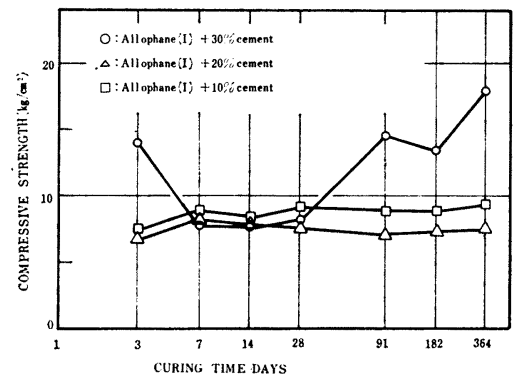

Fig. 37 Variation of compressive strength with curing time in allophane (I)-cement mixture

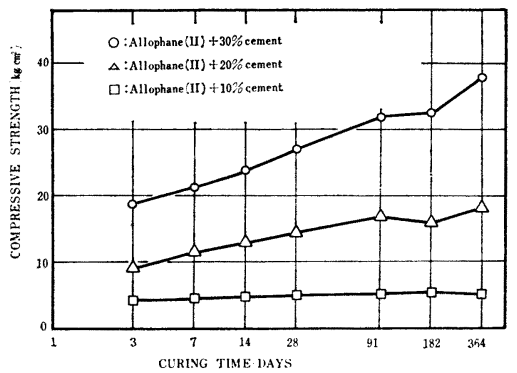

Fig. 38 Variation of compressive strength with curing time in allophane (II)-cement mixture

a little increase in strength occurs after 28 days of curing (Fig. 37). However, there, is a distinct difference in strength between all cement contents in allophane $(\mathrm{A}(\mathrm{II}))$-cement; especially, the strength of 20 and 30 percent cement specimens increases with increasing curing time (Fig. 38). These results concerning the strength development are consistent with those obtained in the X-ray diffraction. The halloysite hydrated included in allophane clay sample seems to have a favorable effect on the strength development of allophane-cement mixtures. Similar effect of halloysite hydrated was reported by Ariizumi and Iwai in their paper concerning the utilization of halloysite as a concrete admixture ${ }^{26)}$.

\section{SUMMARY AND CONCLUSIONS}

Characteristics of cement hydration in the compacted clay mineral-portland cement mixtures differ with the species of clay minerals used. In general, it is certain that the pozzolanic reaction between clay minerals and $\mathrm{Ca}(\mathrm{OH})_{2}$ resulting from cement hydration plays a significant role in clay mineralscement interaction. However, this study revealed that the reaction products in clay minerals-cement mixtures are considerably different from those in clay minerals- $\mathrm{Ca}(\mathrm{OH})_{2}$ ones. Such a difference between them may be attributed to the nature of reactions occuring in both systems. That is to say, in the former system, the hydration of cement and $\mathrm{Ca}(\mathrm{OH})_{2}$-clay minerals interaction take place interacting each other; the latter includes only a reaction process of the more simplified system, i.e. $\mathrm{Ca}(\mathrm{OH})_{2}$ -clay minerals system.

The major conclusions obtained are summarized as follows :

1) Hillebrandite with high lime-silica ratio may be formed at a considerably initial stage of curi$\mathrm{ng}$ as a reaction product in kaolinite- $\mathrm{Ca}(\mathrm{OH})_{2}$ mixtures, transf rming to the $\mathrm{CSH}(\mathrm{I})$ with lower lime-silicaoratio at the long-term curing (182 and 364 days ages). In this respect, Will- 
oughby et $\mathrm{al}^{27}$ ) find the formation of hillebrandite in a kaolinite- $\mathrm{Ca}(\mathrm{OH})_{2}$ mixture by means of the X-ray diffraction and electron microscopic examination. However, the presence of this mineral seems uncertain in kaolinite-cement mixtures.

2) In the initial stage of hydration (within 7 days of curing), the rate of the decrease of the quantity of alite with curing time in both kaolinite-high-early-strength and moderate-heat cement is less than in cement paste. However, the quantity of alite in cement paste decreases a little or little after the initial hydration (from 1 to 7 days of curing), while that in kaolinitecement mixtures continues gradually to decrease with curing time.

3) The hydration of belite in the kaolinite- and bentonite-moderate-heat cement mixtures appears to proceed faster than in cement paste

4) From the changes in D.T.A. curves accompanying the curing time, it is found that the calcium sillicate hydrate with low lime silica ratio would be produced in bentite-cement until 28 days of curing, followed by the transformation to the one with high lime-silica ratio at least after 91 days of curing.

5) A little or little difference between the compressive strength of bentonite-high-early-strength and moderate-heat cement at early curing periods until 28 days is followed by a gradually increasing difference between them. This is the tendency completely reverse to that in the kaolinite-cement and cement mortars.

6) In chlorite-vermiculite mixed-layer mineralcement, the strength increase by the long-term curing after 182 days age is remarkable. It is difficult, from various experimental results, to suppose that such a strength increase is responsile for $\mathrm{CSH}$ (gel) resulting from a usual pozzolanic reaction. Magnesia constituting this mineral probably takes part in the great strength gain at the long-term ages. Several X-ray diffraction peaks suggesting the formation of a magnesium silicate hydrate are detected.

\section{REFERENCES}

1) Moh, Z.C. : Soil Stabilization with Cement and Sodium Additives, Proc. of A.S.C.E., Jour. Soil Mechanics and Foundation Div., 88, pp. 81-105, 1962.

2) Moh, Z.C. : Reactions of Soil Minerals With Cement and Chemicals, Highway Reaearch Record No. 86, pp. 39-61, 1965.

3) Mitchell, J.K. and Jack, S.A.E. : The Fabric of Soil-Cement and its Formation, Proc. the 14 th Natio. Conf. on Clay and Clay Minerals, pp. 279-305, Pergamon Press, 1966.

4) Noble, D.F. : Reactions and Stretngth Development in Portland Cement-Clay Mixtures, Highway Research Record No. 198, pp. 39-56, 1967.

5) Croft, J.B. : The Influence of Soil Mineralogical Composition on Cement Stabilization, Geotechnique Vol. 17, No. 2, pp. 119-135, 1967

6) Metcalf, I.B. : The Effect of High Curing Temperature on the Unconfined Compressive Strength of a Heavy Clay Stabilized with Lime and Cement, Proc. 4 th Aust. -N.Z. Conf. Soil. Mech. Fnd, pp. 126130, 1963.

7) Kawamura, M., Hasaba, S., Nakano, H. and Sugiura, S. : A Role of the Interaction of Clay Minerals with Portland Cement in Soil-Cement Mixture, Transactions of the Japan Society of Civil Engineers Vol. 1. Part 2, 1969.

8) Bezruk, V.M. : Soil-Cement Mixes-A New Structural Material, Dorizdat, Gushosdor-MVD-Ussr, Moscow, pp. 143-172, 1950.

9) Jong, J.G.M., Stein, H.N. and Stevels, J.M. : Influence of Aluminium Hydroxide and Lime on the Hydration of Tricalcium Silicate, Jour. Applied Chemistry Vol. 18, No. 1, pp. 9-17, Jan. 1968.

10) Lipowski, L. : Physikochemishe Ersheinungen beim Erhärten Von Zement-Lehm-Gemischen, ZementKalk-Gips, Nr. 11, pp. 476-483 1968.

11) Noble, D.F. and Ozol, M.A. : Use of Retarders with Cement Treated Soils, Interim Report No. 2, Virginia Highway Research Council, pp. 13., 1968.

12) Tice, J.A. : Use of Retarders with Cement Treated Soils, Interim Report No. 3, Virginia Highway Research Council, p. 37, 1968.

13) Yoshida, M. : Clay Handbook (in Japanese), Gihodo Co. 1966

14) Wang, J.W.H. and Handy, R.L. : Role of $\mathrm{MgO}$ in Soil-Lime Stabilization, H.R.B. Special Report 90, pp. 475-492, 1966.

15) Diamond, S. : Tobermorite and Tobermorite-Like Calcium Silicates Hydrates: Their Properties and Relation to Clay Minerals, Ph. D. thesis, Purdue Univ. Lafayette, Indiana, 1963.

16) Glenn, G.R. : X-ray Studies of Lime-Bentonite Reaction Products, Ph. D. thesis, Iowa State Univ., Ames, Iowa, 1963.

17) EL Jack, S.A. : A Study of Cement-Clay Interaction, $\mathrm{Ph}$. D. thesis, University of Carifornia, Berkeley, 1965.

18) Sloan, R.S. : Early Reaction Determination in two Hydroxide-Kaolinite Systems by Electron Microcopy and Diffraction, Clays and Clay Minerals, 13 th Conf., pp. 331-339, Pergamon Press, New York, 1964.

19) Eades, J.L. and Grim, R.E. : Reaction of Hydrated Lime with Pure Clay Minerals in Soil Stabilization, H.R.B. Bull. 262, 1959.

20) Gillot, J.E. and Sereda, P.J. : Strain in Crystals Detected by X-ray, Nature Vol. 209, No. 5018, pp. 34-36, Jan. 1966.

21) Kantro, D.L., Weise, C.H., Brunauer, S. and Copeland, L.E. : Determination of the Major Compound Contents of Portland Cements by X-ray Diffraction, S.C.I. Monograph No. 18, pp. 364-349, 1964.

22) Kalousek, G.L. and Prebus, A.F. : Crystal Chemistry of Hydrous Calcium Silicates : III, Morphology and Other Properties of Tobermorite and Related Phases, Jour. of the American Ceramic Society Vol. 41, No. 4, pp. 124-132, 1958

23) Bogue, R.H. : The Chemistry of Portland Cement, 2nd Ed., New York, Reinhold, 1955. 
24) Sugiura, S. : Chlorite-Vermiculite Mixed-Layer Clay Mineral from the Noto Mine, Ishikawa Prefecture, Jour. of the Mineralogical Society of Japan Vol. 5, No. 5 (in Japanese), pp. 311-323, 1962.

25) Richartz, W. and Locher, F.W. : Ein Beitrag Zur Morphologie und zum Gefüge des Zement Steins, Zement-Kalk-Gips, Heft 9, pp. 449-459, Sept. 1965.

26) Ariizumi, A. and Iwai, T. : Utilization of Halloysite as a Strength-Improving Agent for Concrete, Proc.
Int. Clay Conf. Vol. 1, Tokyo, pp. 835-841, 1969.

27) Willoughby, D.R., Gross, K.A. Ingles, O.G., Silva, S.R. and Spiers, V.M. : The Identification of Reaction Products in Alkali-Stabilized Clays by Electron Microscopy, X-ray and Electron Diffraction, Proc. of the 4 th Conference of the Australian Road Research Board, 1968.

(Received Oct. 31, 1970) 